\title{
Identification and analytical characterization of the synthetic cathinone $\mathrm{N}$-butylhexedrone
}

\section{1 | INTRODUCTION}

The continuous emergence of new psychoactive substances (NPS) on the drug market remains a global challenge. The United Nations Office on Drugs and Crime (UNODC) and the European Monitoring Centre for Drug and Drug Addiction (EMCDDA) have reported the detection of more than 800 NPS worldwide including more than 670 in Europe (as of the end of 2017). ${ }^{1,2}$ One simple approach used for the preparation of NPS includes the development of so-called designer drugs, which are based on recognizable patterns known from drugs under legislative control. ${ }^{3}$ Synthetic cathinones (representing the second largest number of NPS currently consisting of around 150 compounds $)^{1,2}$ are analogs and derivatives of cathinone (Figure 1), a biologically active alkaloid from the khat plant (Catha edulis), known for its psychoactive properties. ${ }^{4}$ The structure of cathinone offers many possibilities for its modification, which results in the appearance of new derivatives on the drug market each year. ${ }^{5-11}$ For this reason, the detection and identification of synthetic cathinones becomes an important objective for chemists, forensic practitioners, and toxicologists.

Herewith we report the detection and identification of the synthetic cathinone $\mathrm{N}$-butylhexedrone (IUPAC name: 2-(butylamino)-1phenylhexan-1-one, Figure 1). The compound was seized in Russia in November 2018 when found in a shipment originating from China. $\mathrm{N}$-butylhexedrone was first synthesized in the 1960s by Boehringer Ingelheim $\mathrm{GmbH}$ (Germany) from the corresponding $\alpha$-haloketone and amine. ${ }^{12}$ In general, the pharmacological targets of cathinone psychostimulants are dopamine, serotonin, and noradrenaline re-uptake transporters, as well as monoamine receptors. ${ }^{5,13-15}$ Nevertheless, different cathinones differ significantly in their potencies and relative activity toward monoaminergic targets. Hence, pharmacological profiles and, consequently, acute effects, dosage, and toxicity, can vary between the various cathinones. ${ }^{14,15}$ As for $\mathrm{N}$-butylhexedrone, its pharmacological profile is not clear, though it was reported to possess excellent anorexogenic properties and slight stimulating effects on the central nervous system. ${ }^{12}$

To the best of our knowledge, no analytical data for $\mathrm{N}$ butylhexedrone had been reported in the scientific literature. However, during the preparation of our manuscript, some analytical data on $\mathrm{N}$-butylhexedrone appeared on the Internet. ${ }^{16}$ These data included electron ionization (EI) mass spectrometry, Fourier-transform infrared (FT-IR) spectroscopy (salt and free base forms), 1D and 2D nuclear magnetic resonance spectroscopy (NMR), and detection of the protonated molecule using quadrupole time-of-flight (Q-TOF) mass spectrometry. This report presents a full analytical characterization of the seized material identified as $\mathrm{N}$-butylhexedrone. To supplement the analytical data disseminated in the public domain, ${ }^{16}$ a high resolution collision-induced dissociation (CID) mass spectrum was also recorded.

\section{2 | EXPERIMENTAL}

\section{1 | Reagents and samples}

$\mathrm{N}$-butylhexedrone was delivered for expert examination in a forensic laboratory in the Russian Federation as an individual subject in the form of white powder. Preliminary control of uniformity of the sample was carried out by gas chromatography-mass spectrometry (GC-MS) and ultra-high performance liquid chromatography-high resolution mass spectrometry (UHPLC-HRMS) methods.

Acetonitrile (LC-MS grade) was purchased from Panreac (Barcelona, Spain), water (GC, HPLC, and spectrophotometry grade) from Honeywell, Burdick and Jackson (Muskegon, MI, USA), formic acid ( $\geq 98.0 \%$ ), and individual $n$-alkanes from Sigma-Aldrich (Steinheim, Germany) were used for chromatographic analysis. For NMR spectroscopy, $\mathrm{CD}_{3} \mathrm{OD}$ ( $\geq 99.5 \%$, St. Petersburg, Russia) was used. For the preparation of trifluoroacetic derivative of $\mathrm{N}$-butylhexedrone, trifluoroacetic acid anhydride (99\%) was used (purchased from Panreac, Barcelona, Spain).

\section{2 | Sample preparation}

For GC-MS analysis, approximately $1 \mathrm{mg}$ of $\mathrm{N}$-butylhexedrone was dissolved in $1 \mathrm{~mL}$ of methanol. Trifluoroacetic derivative of $\mathrm{N}$ butylhexedrone was prepared according to a reported method. ${ }^{17}$

For UHPLC-HRMS and tandem experiments (UHPLC-HRMS ${ }^{2}$ ), a $5 \mu \mathrm{g} / \mathrm{mL}$ solution of $\mathrm{N}$-butylhexedrone in water was prepared. Prior to instrumental analyses, solutions were diluted with solvents for appropriate concentrations, if required.

\section{3 | Analytical instrument conditions}


<smiles>CC(N)C(=O)c1ccccc1</smiles>

Cathinone

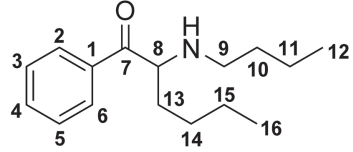

N-Butylhexedrone
FIGURE 1 Chemical structures of cathinone and $\mathrm{N}$-butylhexedrone

mass detector. For chromatographic separation, an HP-5 ms capillary column with 5\%-biphenyl-95\%-dimethylpolysiloxane (30.0 $\mathrm{m} \times 0.25 \mathrm{~mm} \times 0.25 \mu \mathrm{m})$ was used. The oven temperature was maintained at $70^{\circ} \mathrm{C}$ for 1.0 minutes, and then programmed at $15^{\circ}$ $\mathrm{C} / \mathrm{min}$ to $295^{\circ} \mathrm{C}$, which was maintained for 15 minutes. The injector temperature was $250^{\circ} \mathrm{C}$ and the interface temperature $290^{\circ} \mathrm{C}$. Helium in constant linear velocity mode was used as carrier gas; the velocity was $38.5 \mathrm{~cm} / \mathrm{s}$. The mass detector was equipped with an El source. Spectra were recorded in the $\mathrm{m} / \mathrm{z}$ range 29-550 Da.

UHPLC-HRMS analysis was performed with an Agilent 1290 Infinity II UHPLC system connected with a Q-TOF accurate mass detector Agilent 6545 Q-TOF LC-MS system (Agilent Technologies, USA, Santa Clara). Chromatographic separation was achieved on a Zorbax Eclipse Plus C18 RRHD $2.1 \mathrm{~mm} \times 50 \mathrm{~mm} \times 1.8 \mu \mathrm{m}$ reverse phase column with additional $5 \mathrm{~mm}$ guard column. The column thermostat temperature was $35^{\circ} \mathrm{C}$. The mobile phase was a gradient prepared from $0.1 \%$ aqueous formic acid (component A) and $0.1 \%$ formic acid in acetonitrile (component B). The gradient program was as follows: 0 minutes $5 \% \mathrm{~B}$, linear to $100 \% \mathrm{~B}$ at 5 minutes, constant at $100 \%$ B to 7 minutes, back to $5 \%$ B and equilibration for 2 minutes. The flow rate was $0.4 \mathrm{~mL} / \mathrm{min}$. QTOF instrument was operated with an electrospray ion source in positive ion mode. Nitrogen at $350^{\circ} \mathrm{C}$, a flow rate of $10 \mathrm{~L} / \mathrm{min}$, was used as a drying gas. Sheath gas temperature was set at $400^{\circ} \mathrm{C}$, sheath gas flow rate was $12 \mathrm{~L} / \mathrm{min}$. The fragmentor voltage was $90 \mathrm{~V}$. CID spectrum of the precursor ion was recorded with collision energy $22 \mathrm{eV}$. Hexapole collision cell was filled with nitrogen (99.999\%). lons were scanned in the mass ranges of 100-1700 Da in MS mode and 30$300 \mathrm{Da}$ in MS/MS mode.

${ }^{1} \mathrm{H}$ and ${ }^{13} \mathrm{C}$ NMR spectra for $\mathrm{N}$-butylhexedrone were recorded on Bruker 'Avance NEO' spectrometer (Bruker, Switzerland) in $\mathrm{CD}_{3} \mathrm{OD}$ solution $(600 \mathrm{MHz})$ using signals of residual protons from the solvent as internal standard.

FT-IR spectrum was recorded in the range of $3600-650 \mathrm{~cm}^{-1}$ by means of an 'Alpha' FT-IR spectrometer (Bruker, Switzerland) equipped with the attenuated total reflectance (ATR) accessory.

\section{3 | RESULTS AND DISCUSSION}

\section{1 | GC-MS analysis}

An initial comparison with the NIST 17 and Wiley Designer Drugs 2017 mass spectral libraries showed a good degree of matching (match factor of over 800 ) with the spectrum of $\mathrm{N}$-butylhexedrone but also other isomers such as 2-(butyl (methyl)amino)-1- phenylpentan-1-one, 2-(methyl (pentyl)amino)-1-phenylbutan-1-one and 2-(diethylamino)-1-phenylhexan-1-one (see Supporting information, Figures S1-S3). The preparation of the trifluoroacetyl derivative of $\mathrm{N}$-butylhexedrone was included to confirm the presence of the $\mathrm{NH}$ site in the molecule which facilitated the exclusion of isomeric, tertiary candidates such as 2-(butyl (methyl)amino)-1-phenylpentan1-one, 2-(methyl (pentyl)amino)-1-phenylbutan-1-one and 2-(diethylamino)-1-phenylhexan-1-one which were originally retrieved during mass spectral library search.

The signal of the molecular ion was not observed in the El mass spectrum of $\mathrm{N}$-butylhexedrone (Figure $2 \mathrm{~A}$ ). Instead, the only main peak was the iminium ion $(\mathrm{m} / \mathrm{z} 142)$ and a low intensive peak representing the benzoyl ion ( $\mathrm{m} / \mathrm{z}$ 105), both forming as a result of the cleavage of the bond adjacent to the carbonyl group. In contrast, the spectrum of the trifluoroacetic derivative of $\mathrm{N}$-butylhexedrone (Figure 2B) was much more informative. The signal of the molecular ion $(\mathrm{m} / \mathrm{z} 343)$ evidenced the existence of a secondary or primary amino group capable of mono-acylation by the reaction with trifluoroacetic anhydride. Figure 3 presents the proposed formation of fragments under El conditions. The formation of the ions at $\mathrm{m} / \mathrm{z}$ 286, 238, and 105 was due to the cleavage of C-C-bonds at the tertiary carbon atom linked to the nitrogen atom. The ions at $\mathrm{m} / \mathrm{z}$ 196,182 , and 140 possibly resulted from further degradation of the $\mathrm{m} / \mathrm{z} 238$ ion accompanied with sequential elimination of alkenes. Identification by means of mass spectra could be additionally proved by generalized log-linear retention indices ${ }^{18}$ of $\mathrm{N}$-butylhexedrone and its trifluoroacetyl derivative (1830 and 1877, respectively).

\section{2 | UHPLC-HRMS and UHPLC-HRMS/MS analysis}

The total ion chromatogram of the solution of the compound displayed a distinct peak with retention time of 2.38 minutes. The mass spectrum of the compound contained a peak of its protonated molecule ( $\mathrm{m} / \mathrm{z}$ 248.2013), which corresponded to the molecular formula $\mathrm{C}_{16} \mathrm{H}_{25} \mathrm{NO}$. Accurate and exact masses for the compound were 247.1940 and 247.1936, respectively, indicating a mass accuracy of $-1.5 \mathrm{ppm}$. No other compounds were found in the chromatogram.

Additional data on the structure of the compound were obtained from high-resolution collision-induced dissociation experiments using the protonated molecule (Figure 4). An intense peak of $\mathrm{m} / \mathrm{z}$ 230.1903 ion in the spectrum resulted from the release of water, which is characteristic for cathinones. ${ }^{10,19,20}$ This ion might be stabilized due to a cyclic indole-like structure. ${ }^{10}$ Further fragmentation of $\mathrm{m} / \mathrm{z} 230.1903$ was associated with elimination of alkenes of different length and formation of $\mathrm{m} / \mathrm{z} 188.1434,174.1277,132.0808$, and 118.0651, respectively. The formation of ions $\mathrm{C}_{9} \mathrm{H}_{20} \mathrm{~N}^{+}(\mathrm{m} / \mathrm{z}$ 142.1590) and $\mathrm{C}_{7} \mathrm{H}_{5} \mathrm{O}^{+}(\mathrm{m} / \mathrm{z} 105.0335)$ was thought to be due to the $\alpha$-cleavage of the carbon bond in the carbonyl group. 


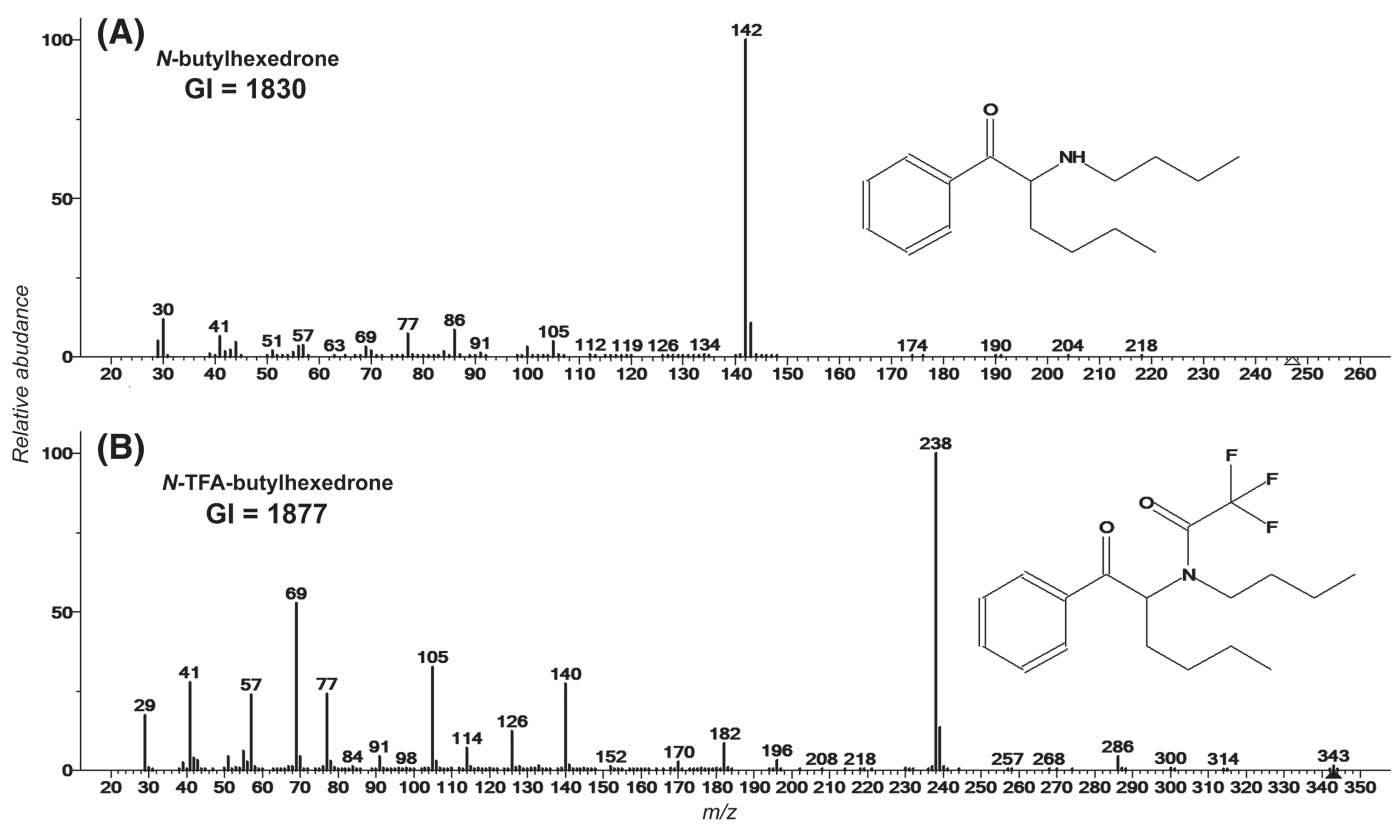

FIGURE 2 El mass spectra and generalized log-linear retention indices (GI) of A, N-butylhexedrone; and B, trifluoroacetic (TFA) derivative of $\mathrm{N}$-butylhexedrone

\section{3 | NMR spectroscopy}

The ${ }^{1} \mathrm{H}$ NMR spectrum of $\mathrm{N}$-butylhexedrone (Table 1 and Figure S4) contained the signals of five aromatic protons in the range of 7.6$8.1 \mathrm{ppm}$ : two-proton doublet, one-proton doublet of doublets and two-proton doublet of doublets (with the same spin-spin coupling constant (SSCC) of ${ }^{3} \mathrm{~J}=7.2 \mathrm{~Hz}$ ). This observation along with the value of the chemical shifts proved that the compound contained a monosubstituted phenyl ring. A one-proton triplet with $\mathrm{SSCC}^{3} \mathrm{~J}=5.4 \mathrm{~Hz}$ at $5.23 \mathrm{ppm}$ was found upfield and correlated with a methine proton located between the carbonyl group and the nitrogen atom. The protons of the alkyl fragments were displayed as two three-proton triplets at 0.83 and $0.98 \mathrm{ppm}$ with $\mathrm{SSCC}^{3} \mathrm{~J}=7.2 \mathrm{~Hz}$, which corresponded to the terminal methyl groups. The two-proton quintet at $1.75 \mathrm{ppm}$ with $\mathrm{SSCC}^{3} \mathrm{~J}=6.0 \mathrm{~Hz}$ and a series of multiplets in the range from 1.4 to $3.1 \mathrm{ppm}$, represented the 10 methylene protons.

In the ${ }^{13} \mathrm{C}$ NMR spectrum for $\mathrm{N}$-butylhexedrone (Table 1 and Figure S5), the signals from the seven carbon atoms (one corresponding to the carbonyl carbon at $197.0 \mathrm{ppm}$ ) and the others referring to the atoms of carbon of phenyl ring [129.9 (2C), 130.4 (2C), 135.3 and $136.1 \mathrm{ppm}$ ] were detected. The signal of methine carbon appeared at $63.5 \mathrm{ppm}$, and the signals belonging to the two methyl groups were observed at $13.9 \mathrm{ppm}$. The carbon chemical shifts linked to the six methylene groups were found at 20.9, 23.4, 27.3, 29.4, 31.4, and $48.1 \mathrm{ppm}\left(\mathrm{NH}-\mathrm{CH}_{2}\right)$.

The signals in ${ }^{1} \mathrm{H}$ and ${ }^{13} \mathrm{C}$ spectra were assigned based on twodimensional experiments 2D COSY, 2D ${ }^{1} \mathrm{H}^{-13} \mathrm{C}$ gHSQC, and 2D ${ }^{1} \mathrm{H}-{ }^{13} \mathrm{C}$ gHMBC experiments. The $2 \mathrm{D}{ }^{1} \mathrm{H}^{13} \mathrm{C}$ gHSQC spectrum (Figure $\mathrm{S} 6$ ) helped with the assignments of the carbons in the aromatic ring: 136.11 (C-4), 135.34 (C-1), 130.41 (C-3, C-5), 129.94 (C-2, C-6) as well as protons $\mathrm{H}-8$ and $\mathrm{H}-13$ : 63,53 (C-8), 31,43 (C-13). The aliphatic substituents were unambiguously determined by means of $2 \mathrm{D}$ COSY $\left({ }^{1} \mathrm{H}^{-1} \mathrm{H}\right)$ (Figure S7). The most informative and characteristic cross-peaks in 2D-COSY were: $\mathrm{H}-9 / \mathrm{H}-10, \mathrm{H}-10 / \mathrm{H}-11, \mathrm{H}-11 / \mathrm{H}-12$, $\mathrm{H}-8 / \mathrm{H}-13, \mathrm{H}-13 / \mathrm{H}-14, \mathrm{H}-14 / \mathrm{H}-15, \mathrm{H}-15 / \mathrm{H}-16$. As for the $2 \mathrm{D}$ ${ }^{1} \mathrm{H}-{ }^{13} \mathrm{C}$ gHMBC spectrum (Figures S8-S10), the cross-peaks $\mathrm{C}-7 / \mathrm{H}-$
FIGURE 3 Scheme of formation of the main characteristic ions in the El spectrum of trifluoroacetic derivative of $\mathrm{N}$-butylhexedrone

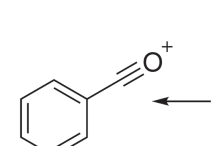

$\mathrm{C}_{7} \mathrm{H}_{5} \mathrm{O}^{+}$

$\mathrm{m} / \mathrm{z}=105$<smiles>[Te][Te]</smiles>

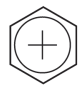

$\mathrm{C}_{6} \mathrm{H}_{5}{ }^{+}$

$\mathrm{m} / \mathrm{z}=77$<smiles>CCCC(C(=O)c1ccccc1)N(C(=O)C(F)(F)F)C(=O)C(F)(F)F</smiles>

$\mathrm{m} / \mathrm{z}=343$

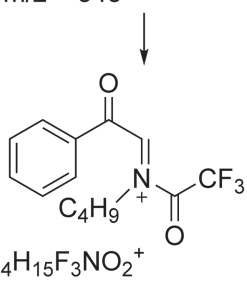

$\mathrm{C}_{14} \mathrm{H}_{15} \mathrm{~F}_{3} \mathrm{NO}_{2}$ $\mathrm{m} / \mathrm{z}=286$

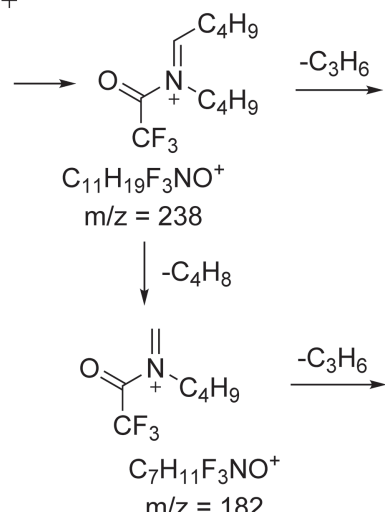

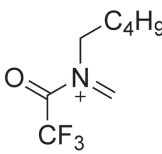
$\mathrm{C}_{8} \mathrm{H}_{13} \mathrm{~F}_{3} \mathrm{NO}^{+}$ $\mathrm{m} / \mathrm{z}=196$<smiles>C[13CH3]</smiles><smiles>C=CN(C)C(=O)C(F)(F)F</smiles>

$\mathrm{C}_{4} \mathrm{H}_{5} \mathrm{~F}_{3} \mathrm{NO}^{+}$ $\mathrm{m} / \mathrm{z}=140$ 
(A)

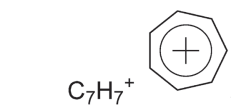

$$
\mathrm{C}_{7} \mathrm{H}_{7}^{+}
$$
$\mathrm{C}_{7} \mathrm{H}_{7}{ }^{+}$
$\mathrm{m} / \mathrm{z} 91.0542$ $(\Delta=-2.36 \mathrm{ppm})$

$$
\mathrm{C}_{7} \mathrm{H}_{5} \mathrm{O}^{+}
$$

$\mathrm{m} / \mathrm{z} 105.0335$

$(\Delta=-0.74 \mathrm{ppm})$

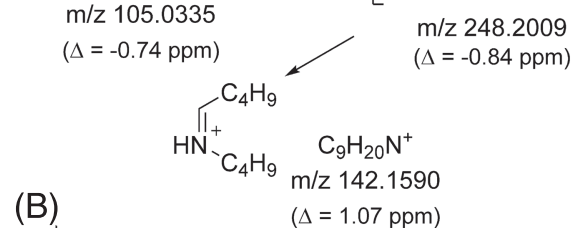

(B) $\quad(\Delta=1.07 \mathrm{ppm})$

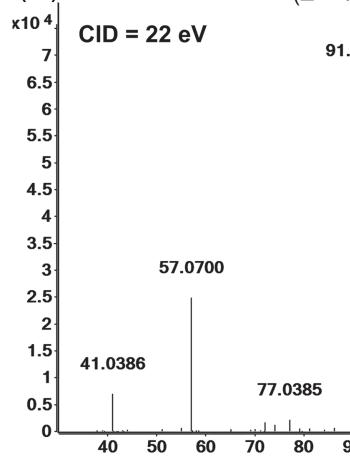

1.0544

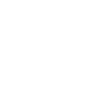

118.0655

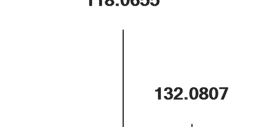

$\mathrm{C}_{8} \mathrm{H}_{8} \mathrm{~N}^{+}$

$\mathrm{m} / \mathrm{z} 118.0651$

$(\Delta=-3.09 \mathrm{ppm})$<smiles>c1ccc2[nH]ccc2c1</smiles>

$\mathrm{C}_{9} \mathrm{H}_{10} \mathrm{~N}^{+}$

$\mathrm{m} / \mathrm{z} 132.0808$

$(\Delta=0.37 \mathrm{ppm})$

FIGURE 4 A, Scheme of formation of the main characteristic ions in the CID spectrum of $N$-butylhexedrone. B, CID spectrum of $N$ butylhexedrone (retention time RT $=2.38$ minutes) at collision energy of $22 \mathrm{eV}$

\begin{tabular}{|c|c|c|}
\hline Location & $\begin{array}{l}\mathrm{CD}_{3} \mathrm{OD}(600 \mathrm{MHz}) \\
{ }^{1} \mathrm{H}\end{array}$ & ${ }^{13} \mathrm{C}$ \\
\hline 1 & - & 135.3 \\
\hline 2 & $8.08\left(\mathrm{~d}, 1 \mathrm{H},{ }^{3} \mathrm{~J}=7.2 \mathrm{~Hz}\right)$ overlapping & 129.9 \\
\hline 3 & $7.61\left(\mathrm{dd}, 1 \mathrm{H},{ }^{3} \jmath_{1}={ }^{3} J_{2}=7.2 \mathrm{~Hz}\right)$ overlapping & 130.4 \\
\hline 4 & $7.75\left(\mathrm{dd}, 1 \mathrm{H},{ }^{3} J_{1}={ }^{3} J_{2}=7.2 \mathrm{~Hz}\right)$ & 136.1 \\
\hline 5 & $7.61\left(\mathrm{dd}, 1 \mathrm{H},{ }^{3} J_{1}={ }^{3} J_{2}=7.2 \mathrm{~Hz}\right)$ overlapping & 130.4 \\
\hline 6 & $8.08\left(\mathrm{~d}, 1 \mathrm{H},{ }^{3} \mathrm{~J}=7.2 \mathrm{~Hz}\right)$ overlapping & 129.9 \\
\hline 7 & - & 197.0 \\
\hline 8 & $5.23\left(\mathrm{t}, 1 \mathrm{H},{ }^{3} \mathrm{~J}=5.4 \mathrm{~Hz}\right)$ & 63.5 \\
\hline 9 & $2.95-3.09(\mathrm{~m}, 2 \mathrm{H})$ & 48.1 \\
\hline 10 & $1.75\left(\mathrm{q}, 2 \mathrm{H},{ }^{3} \mathrm{~J}=6.0 \mathrm{~Hz}\right)$ & 29.4 \\
\hline 11 & $1.42-1.45(\mathrm{~m}, 2 \mathrm{H})$ & 20.9 \\
\hline 12 & $0.98\left(\mathrm{t}, 3 \mathrm{H},{ }^{3} \mathrm{~J}=7.2 \mathrm{~Hz}\right)$ & 13.9 \\
\hline 13 & $2.01-2.03(\mathrm{~m}, 2 \mathrm{H})$ & 31.4 \\
\hline 14 & $1.22-1.38(\mathrm{~m}, 2 \mathrm{H})$ & 27.3 \\
\hline 15 & $1.13-1.22(\mathrm{~m}, 2 \mathrm{H})$ & 23.4 \\
\hline 16 & $0.83\left(\mathrm{t}, 3 \mathrm{H},{ }^{3} \mathrm{~J}=7.2 \mathrm{~Hz}\right)$ & 13.9 \\
\hline
\end{tabular}

TABLE 1 NMR spectra data for N-butylhexedrone
8, $\mathrm{H}-13, \mathrm{H}-2-6, \mathrm{C}-8 / \mathrm{H}-9, \mathrm{C}-1 / \mathrm{H}-8$ were useful for the characterization of the structure.

\section{4 | FT-IR spectroscopy}

The FT-IR spectrum for N-butylhexedrone (Figure S11) contained a strong absorption band at $1687 \mathrm{~cm}^{-1}$ which is characteristic for valence stretching of the carbonyl group. It is also worthy to note the intense band at $707 \mathrm{~cm}^{-1}$ that was thought to correlate with nonplanar bending vibrations of $\mathrm{C}-\mathrm{H}$ bonds of the phenyl ring. A set of bands in the range of $2400-2700 \mathrm{~cm}^{-1}$ was considered indicative of the amino group existing in the salt form.

\section{4 | CONCLUSION}

In summary, the present work reports on the identification and characterization of $\mathrm{N}$-butylhexedrone, one more representative of synthetic cathinones that are widely spread across the global NPS market. Even though the compound was originally investigated as a potential medicine, its pharmacological profile and toxicological properties are unknown. The patterns of mass spectral fragmentation of the compound after electron ionization and collision-induced dissociation were studied. We believe that the achieved results aid with the detection and identification of $\mathrm{N}$-butylhexedrone in different media and thus will be helpful for forensic, clinical and forensic toxicology laboratories. 


\section{ORCID}

Vadim Shevyrin (D) https://orcid.org/0000-0002-0369-0786

Vadim Shevyrin iD

Oleg Eltsov

Yuri Shafran

Ural Federal University named after the first President of Russia B. N. Yeltsin, Institute of Chemical Engineering, 19 Mira Str, 620002

Ekaterinburg, Russian Federation

\section{REFERENCES}

1. World Drug Report 2018. Analysis of drug markets. Opiates, cocaine, cannabis, synthetic drugs, United Nations Office on Drugs and Crime, Vienna, 2018. https://www.unodc.org/wdr2018/prelaunch/WDR18_ Booklet_3_DRUG_MARKETS.pdf. Accessed 26.02.2019

2. European Drug Report 2018, EMCDDA-Europol joint publication, Lisbon, 2018. http://www.emcdda.europa.eu/system/files/publications/ 8585/20181816_TDAT18001ENN_PDF.pdf. Accessed 26.02.2019.

3. Brandt SD, King LA, Evans-Brown M. The new drug phenomenon. Drug Test Anal. 2014;6(7-8):587-597.

4. Patel NB. Khat-a natural source of cathinone. In: Zawilska JB, ed. Synthetic Cathinones: Novel Addictive and Stimulatory Psychoactive Substances. Cham: Springer International Publishing; 2018:25-40.

5. Majchrzak M, Celinski R, Kus P, Kowalska T, Sajewicz M. The newest cathinone derivatives as designer drugs: an analytical and toxicological review. Forensic Toxicol. 2018;36(1):33-50.

6. Gaspar H, Bronze S, Oliveira Cet al. Proactive response to tackle the threat of emerging drugs: synthesis and toxicity evaluation of new cathinones. Forensic Sci Int 2018;290:146-156.

7. Rojkiewicz M, Kus P, Kusz J, Ksiazek M. Spectroscopic and crystallographic characterization of two cathinone derivatives: 1-(4fluorophenyl)-2-(methylamino)pentan-1-one (4-FPD) hydrochloride and 1-(4-methylphenyl)-2-(ethylamino)pentan-1-one (4-MEAP) hydrochloride. Forensic Toxicol. 2018;36(1):141-150.

8. Błażewicz A, Bednarek E, Sitkowski J, et al. Identification and structural characterization of four novel synthetic cathinones: $a$ methylaminohexanophenone (hexedrone, HEX), 4-bromoethcathinone (4-BEC), 4-chloro-a-pyrrolidinopropiophenone (4-cl-PPP), and 4bromo-a-pyrrolidinopentiophenone (4-Br-PVP) after their seizures. Forensic Toxicol. 2017;35(2):317-332.

9. Carlsson A, Sandgren V, Svensson S, et al. Prediction of designer drugs: synthesis and spectroscopic analysis of synthetic cathinone analogs that may appear on the Swedish drug market. Drug Test Anal. 2018; 10(7):1076-1098.

10. Apirakkan O, Frinculescu A, Shine T, et al. Analytical characterization of three cathinone derivatives, 4-MPD, 4F-PHP and bk-EPDP, purchased as bulk powder from online vendors. Drug Test Anal. 2018;10(2): 372-378.

11. Machado Y, Coelho Neto J, Barbosa PEN, Lordeiro RA, Alves RB. Brephedrone: a new psychoactive substance seized in Brazil. Forensic Sci Int. 2017;275:302-307.

12. Boehringer Ingelheim GMBH. a-Aminoketone derivatives. Great Britain patent GB1069797. 24 May 1967.

13. Simmons SJ, Leyrer-Jackson JM, Oliver CF, et al. DARK classics in chemical neuroscience: cathinone-derived psychostimulants. ACS Chem Nerosci. 2018;9(10):2379-2394.

14. Simmler LD. Monoamine transporter and receptor interaction profiles of synthetic cathinones. In: Zawilska JB, ed. Synthetic Cathinones: Novel Addictive and Stimulatory Psychoactive Substances. Cham: Springer International Publishing; 2018:97-115.

15. Gołembiowska K, Kamińska K. Effects of synthetic cathinones on brain neurotransmitters. In: Zawilska JB, ed. Synthetic Cathinones: Novel Addictive and Stimulatory Psychoactive Substances. Cham: Springer International Publishing; 2018:117-124.

16. Butyl-hexedrone. https://www.policija.si/apps/nfl_response_web/0_ Analytical_Reports_final/Butylhexedrone-ID-HIFS-011.pdf. Accessed 12.05.2019

17. Shevyrin V, Kupriyanova O, Lebedev AT, et al. Mass spectrometric properties of $\mathrm{N}$-(2-methoxybenzyl)-2-(2,4,6-trimethoxyphenyl) ethanamine (2,4,6-TMPEA-NBOMe), a new representative of designer drugs of NBOMe series and derivatives thereof. J Mass Spectrom. 2016;51(10):969-979.

18. Stolyarov BV, Savinov IM, Vitenberg AG, et al. Practical Gas and Liquid Chromatography (in Russian). St. Petersburg: St. Petersburg University; 2002.

19. Fabregat-Safont D, Sancho JV, Hernández F, Ibáñez M. Rapid tentative identification of synthetic cathinones in seized products taking advantage of the full capabilities of triple quadrupole analyzer. Forensic Toxicol. 2019;37(1):34-44.

20. Fornal E. Study of collision-induced dissociation of electrospray-generated protonated cathinones. Drug Test Anal. 2014;6(7-8):705-715.

\section{SUPPORTING INFORMATION}

Additional supporting information may be found online in the Supporting Information section at the end of the article. 